\title{
Implementasi Pendidikan Karakter Dalam Pembelajaran IPA di MIN Pemangkat Kabupaten Sambas Kalimantan Barat
}

\author{
Purniadi Putra \\ IAIS Sultan Muhammad Syafiuddin Sambas \\ Kalimantan Barat \\ Email: usupurniadi@yahoo.com
}

\begin{abstract}
This study aims to know and examine more deeply about the implementation of character education in science learning in MIN Pemangkat Sambas regency, knowing and deepening about the character values implanted in science learning in MIN Pemangkat Sambas regency. This research is qualitative descriptive research. The location of research is in Madrasah Ibtidaiyah Negeri Pemangkat Sambas Regency using primary data source and sekuder is the technique of analyzing data used interview and documentation, data analysis is qualitative analysis. The results of this study indicate that implementation of character education in science learning in MIN Pemangkat Sambas Regency implemented in three stages of planning, implementation, evaluation and follow up. Priority character values are character values that must be instilled by educators in science learning activities. Character values in the priorities embedded include honest values, discipline, hard work and responsibility.
\end{abstract}

Keywords: Implementation of Character Education in Science Lesson

\begin{abstract}
Abstrak
Penelitian ini bertujuan untuk mengetahui dan mengkaji lebih dalam tentang implementasi pendidikan karakter dalam pembelajaran IPA di MIN Pemangkat Kabupaten Sambas, mengetahui dan mengkaji lebih dalam tentang nilai-nilai karakter yang ditanamkan dalam pembelajaran IPA di MIN Pemangkat Kabupaten Sambas. Penelitian ini adalah penelitian deskriptif kualitatif.Lokasi penelitian yaitu di Madrasah Ibtidaiyah Negeri Pemangkat Kabupaten Sambas menggunakan sumber data primer dan sekuder adalah yaitu teknik menganalisis data yang digunakan wawancara dan dokumentasi, analisis datanya adalah analisis kualitatif. Hasil penelitian ini menunjukkan bahwa implementasi pendidikan karakter dalam pembelajaran IPA di MIN Pemangkat Kabupaten Sambas dilaksanakan dalam tiga tahapan yaitu perencanaan, pelaksanaan, evaluasi dan tindak lanjut. Nilai-nilai karakter prioritas merupakan nilai-nilai karakter yang wajib ditanamkan pendidik dalam kegiatan pembelajaran IPA. Nilainilai karakter dalam prioritas yang ditanamkan meliputi nilai jujur, disiplin, kerja keras dan tanggung jawab.
\end{abstract}

Kata Kunci: Implementasi Pendidikan Karakter dalam Pembelajaran IPA

\section{A. Pendahuluan}

Pendidikan karakter merupakan salah satutran topik pendidikan yang saat ini mendapat sorotan dan perhatian yang banyak baik dari pemerintah, civitas akademik maupun masyarakat. Terlebih dengan dirasakannya berbagai ketimpangan hasil pendidikan yang ditunjukkan dari perilaku lulusan pendidikan saat ini. Ketimpangan tersebut berupa meningkatnya tawuran antarpelajar, serta bentuk-bentuk kenakalan 
remaja lainnya terutama di kota-kota besar, pemerasan/kekerasan (bullying), fenomena suporter sepak bola, penggunaan narkoba, dan lain-lain.( Muchlas Samani \& Hariyanto, 2011: 2)

Thomas Lickona, sebagaimana yang ditulis oleh Masnur Muslich, (2013: 3536), ada sepuluh tanda-tanda zaman yang harus diwaspadai karena jika tanda-tanda ini sudah ada, berarti sebuah bangsa sedang menuju jurang kehancuran. Tanda-tanda yang dimaksud adalah (1) meningkatnya kekerasan dikalangan remaja, (2) penggunaan bahasa dan kata-kata yang memburuk, (3) pengaruh peer-group yang kuat dalam tindak kekerasan, (4) meningkatnya perilaku merusak diri, seperti penggunaan narkoba, alkohol dan seks bebas, (5) semakin kaburnya pedoman moral baik dan buruk, (6) menurunnya etos kerja, (7) semakin rendahnya rasa hormat kepada orang tua dan guru, (8) rendahnya rasa tanggung jawab individu dan warga Negara, (9) membudayanya ketidakjujuran, dan (10) adanya rasa saling curiga dan kebencian sesama. Ternyata jika dicermati sekarang kesepuluh tanda zaman ini sudah membudaya di Indonesia.

Sebagaimana yang termaktub dalam Al-Qur'an, dalam Teungku Muhammad Hasbi Ash Shiddiqi, (2002: 1032) manusia adalah makhluk dengan berbagai karakter.Dalam kerangka besar manusia mempunyai dua karakter yang berlawanan, yaitu karakter baik dan buruk.

Pendidikan yang berdasarkan nilai-nilai hidup dapat tercermin dalam pendidikan karakter, yakni proses pendewasaan diri individu mulai dari lingkungan keluarga, sekolah dan masyarakat. Tantangan saat ini dan ke depan adalah bagaimana kita mampu menempatkan pendidikan karakter sebagai suatu kekuatan bangsa. Oleh karena itu kebijakan dan implementasi pendidikan yang berbasis karakter menjadi sangat penting dan strategis dalam rangka membangun bangsa ini.Hal ini tentunya juga menuntut adanya dukungan yang kondusif dari pranata politik, sosial, ekonomi dan budaya bangsa.

Para pemerhati pendidikan hendaknya mampu memberikan sosialisasi secara komprehensif terkait dengan pendidikan karakter.Nilai-nilai yang terdapat pada setiap mata pelajaran diarahkan kepada pendidik dan peserta didik dalam penerapan pendidikan karakter.Kegiatan integrasi pendidikan karakter salah satunya dengan mata pelajaran IPA diharapkan dapat memberikan kesan bahwa dalam pembelajaran IPA sebenarnya terdapat nilai-nilai karakter yang belum disadari dan perlu digali yang nantinya dapat dioptimalkan dalam membangun karakter peserta didik.

Dengan demikian, maka sudah seharusnya semua mata pelajaran harus menyisipkandan menanamkan nilai-nilai iman dan takwa (imtak) serta akhlak mulia,termasuk diantaranya dalam mata pelajaran IPA. Mata pelajaran IPA adalahsuatu mata pelajaran yang memuat kumpulan teori yang sistematis, penerapannya secara umum terbatas pada gejala alam, lahir dan berkembangmelalui metode ilmiah seperti observasi dan eksperimen serta menuntut sikapilmiah seperti rasa ingin tahu, terbuka, jujur, dan sebagainya.(Trianto, 2010: 136-137).

Dari definisi di atas, kita dapat mengetahui bahwa dalam pembelajaran IPA juga berperan dalam penanaman nilai-nilai pendidikan karakter yang harus dimiliki oleh 
setiap peserta didik setelah melakukan sebuah proses pembelajaran. Hal tersebut selaras dengan tujuan pendidikan IPA di Indonesia yang tertuang dalam Permendiknas Nomor 22 Tahun 2006 tentang Standar Isi yang menyatakan bahwa mata pelajaran IPA di SD/MI bertujuan agar peserta didik memiliki kemampuan sebagai berikut.

1. Memperoleh keyakinan terhadap kebesaran Tuhan Yang Maha Esaberdasarkan keberadaan, keindahan dan keteraturan alam ciptaan-Nya.

2. Mengembangkan pengetahuan dan pemahaman konsep-konsep IPA yangbermanfaat dan dapat diterapkan dalam kehidupan sehari-hari.

3. Mengembangkan rasa ingin tahu, sikap positif dan kesadaran tentangadanya hubungan yang saling memengaruhi antara IPA, lingkungan,teknologi dan masyarakat.

4. Mengembangkan keterampilan proses untuk menyelidiki alam sekitar,memecahkan masalah dan membuat keputusan.

5. Meningkatkan kesadaran untuk berperan serta dalam memelihara, menjagadan melestarikan lingkungan alam.

6. Meningkatkan kesadaran untuk menghargai alam dan segalaketeraturannya sebagai salah satu ciptaan Tuhan.

7. Memperoleh bekal pengetahuan, konsep dan keterampilan IPA sebagaidasar untuk melanjutkan pendidikan ke jenjang selanjutnya (SMP/MTs)

Adapun nilai-nilai pendidikan karakter dalam pembelajaran IPA diantaranya dapat berupa kemampuan memecahkan masalah yang ada dalam kehidupan seharihari.Dalam pembelajaran IPA, peserta didik diharapkan mampu mengamalkan nilainilai tersebut tidak hanya pada saat pelaksanaan pembelajaran dalam kelas, melainkan juga dapat menerapkannya dalam kehidupan sehari-hari. Hal ini bertujuan agar peserta didik memiliki pemikiran kritis, sistematis, kreatif, mandiri, serta dapat bekerjasama dengan orang lain. Cara berpikir ini dapat dikembangkan melalui pembelajaran IPA, karena IPA memiliki struktur dan keterkaitan yang kuat dan jelas antar konsep, sehingga memungkinkan peserta didik berpikir logis.Nilai yang telah disebutkan di atas pada saat ini dikenal dengan konsep pendidikan karakter.

MIN Pemangkat merupakan salah satu lembaga pendidikan dasar yang secara spesifik mencanangkan dan menerapkan pendidikan karakter.Hal itu setidaknya terlihat dari tujuan yang hendak dicapai (visi misi madrasah) dan berbagai kegiatan yang menunjangnya seperti melalui kegiatan pembiasaan dan ekstrakurikuler. Kegiatan pembiasaan yang dilakukan antara lain shalat dzuhur berjamaah, tadarus al-Qur'an, apel pagi dan lain sebagainya. Kemudian kegiatan ekstrakurikuler berupa kegiatan-kegiatan pengembangan diri antara lain pramuka, drum band,qiro'ah, kesenian dan TPA.

Madrasah Ibtidaiyah Negeri Pemangkat beralamat di Jalan Penjajap Timur Kecamatan Pemangkat Kabupaten Sambas.Di madrasah ini (khususnya kelas V), pendidikankarakter dimasukkan/implementasikan secara implisit terintegrasi dengankegiatan belajar mengajar di kelas.Adapun nilai-nilai karakter yangditanamkan dalam pembelajaran IPA yaitu jujur, disiplin, tanggung jawab dankerja keras.Nilai-nilai 
karakter yang dikembangkan di madrasah tersebutmengacu kepada konsep nilai-nilai karakter yang dikeluarkan olehKementerian Pendidikan Nasional (Kemendiknas).(Visti Anggraini 30 Januari 2017)

Dalam upaya mendukung tujuan tersebut, perlu ditanamkan pendidikan karakter dalam proses pembelajaran ke dalam diri anak-anak sebagai peserta didik yang bertujuan antara lain untuk mengembangkan potensi peserta didik agar menjadi manusia berhati baik, berpikiran baik, dan berperilaku baik. Salah satunya yakni melalui pembelajaran IPA. Hal ini dikarenakan dalam pembelajaran IPA selain terdapat aspek produk dan proses juga terdapat aspek sikap. Adanya pembentukan sikap yang baik dari peserta didikdiharapkan dapat membentuk karakter yang baik pula, sehingga dihaparkandapat membangun kehidupan bangsa yang lebih berhasil.Karena keberhasilan suatu bangsa dapat dicerminkan melalui kualitas sumber daya manusia di dalamya.

Dari sinilah muncul pemikiran penulis bahwa pembelajaran IPA dapat dijadikan wahana dalam menanamkan nilai-nilai pendidikan karakter kepada peserta didik. Oleh karena itu, perlu adanya penelitian lebih lanjut terkait dengan kegiatan belajar mengajar mata pelajaran IPA yang terintegrasikan dengan nilai-nilai pendidikan karakter di madrasah yang bersangkutan.

\section{B. Pembahasan}

\section{Ilmu Pengetahuan Alam}

IPA atau yang sering disebut sebagai sains merupakan ilmu yang memberikan sumbangan luar biasa terhadap perkembangan teknologi. Trowbridge dan Byebee (1986) mendefinisikan bahwa "Science is a body of knowledge, formed y a process of continuous inquiry, and encompassing the people who are engaged in the scientific enterprice". Berdasarkan hal tersebut IPA sebagai tubuh dari pengetahuan yang dibentuk melalui proses inkuiri yang terus menerus dan dilakukan orang yang bergerak dalam bidang sains. Jadi sains atau IPA terdiri dari keterampilan proses yang dilengkapi dengan sikap ilmiah untuk menemukan atau membuktikan suatu konsep atau prinsip. IPA berkaitan dengan cara mencari tahu tentang fenomena alam secara sistematis, sehingga IPA bukan hanya penguasaan kumpulan pengetahuan yang berupa fakta-fakta, konsep-konsep, atau prinsip-prinsip saja tetapi juga merupakan suatu proses penemuan (Lampiran Permendiknas No. 22 Tahun 2006).

Berdasarkan beberapa pendapat di atas, dapat disimpulkan bahwa IPA merupakan kumpulan pengetahuan yang tersusun secara sistematis tentang gejala alam dan perkembangannya tidak hanya ditunjukkan oleh fakta-fakta tapi juga timbulnya metode ilmiah dan sikap ilmiah. Berdasarkan beberapa definisi di atas, dapat disimpulkan bahwa hakikat IPA meliputi produk, proses dan sikap. Untuk memperoleh produk IPA yang berupa fakta, konsep, prinsip, hukum, maupun model dilakukan melalui proses ilmiah. Proses ilmiah memerlukan suatu keterampilan proses yang biasa disebut keterampilan proses sains. 
Zuhdan (2013), menyatakan keterampilan proses sains meliputi proses mengamati, mengukur, menginterpretasi, memanipulasi, melakukan hipotesis, menarik kesimpulan dan mengkomunikasikan. Adapun hakikat IPA sebagai sikap menunjukkan nilai-nilai yang menyertai atau muncul ketika proses sains dilakukan yang bisasa disebut sebagai sikap ilmiah.

Sikap ilmiah selalu membersamai kegiatan atap pemikiran ilmiah.Nilai-nilai tersebut meliputi rasa ingin tahu, terbuka, berpikir logis, kritis, kreatif, inovatif, jujur, disiplin, mandiri, bertanggung jawab, tidak mudah putus asa.Proses pembelajaran IPA yang dilaksanakan di sekolah seharusnya mengimplementasikan hakikat IPA itu sendiri. Pembelajaran tidak hanya mengutamakan produk saja, malainkan juga proses dan sikap. Diharapkan dengan sikap yang baik, siswa akan memperoleh prestasi yang baik pula.(Amjad Pitafi and Muhammad Farooq, 2012 : 22-23, 95-53).

\section{Pendidikan Karakter}

Untuk memahami konsep pendidikan karakter secara komprehesif, dapat diperoleh dari beberapa pengertian dan komentar dari para ahli. Pendidikan karakter seringkali dikatakan sebagai nilai, norma, budi pekerti dan moral hal ini di sebabkan karena seringkali banyak dirumuskan dalam berbagai konsep yang berbeda-beda.

Secara etimologis, dalam Tim Redaksi Tessaurus Bahasa Indonesia, (2008: 229) kata "karakter" bisa berarti tabiat, sifat-sifat kejiwaan, akhlak atau budi pekerti yang membedakanseseorang dengan yang lain atau watak. Orang yang berkarakter berarti orang yang memiliki watak, kepribadian, budi pekerti, atau akhlak.Dengan makna seperti ini, berarti karakter identik dengan kepribadian atau akhlak.Kepribadian merupakan ciri atau karakteristik atau sifat khas dari diri seseorang yang bersumber dari bentukan-bentukan yang diterima dari lingkungan, misalnya keluarga pada masa kecil dan juga bawaan sejak lahir. (Doni Koesoema, 2007: 80).

Adapun secara terminologis, makna karakter dikemukakan oleh Thomas Lickona (1991: 51), menurutnya karakter adalah "a reliable inner disposition to respond to situations in a morally good way". Selanjutnya, dia menambahkan, "character so conceived has three interrelated parts: moral knowing, moral feeling, and moral behavior". Menurut Lickona, karakter mulia (good character) meliputi pengetahuan tentang kebaikan, lalu menimbulkan komitmen (niat) terhadap kebaikan dan akhirnya benar-benar melakukan kebaikan. Dengan kata lain, karakter mengacu kepada serangkaian pengetahuan (cognitives), sikap (attitudes), dan motivasi (motivations), serta perilaku (behaviors) dan ketrampilan (skills).

Menurut David Elkind \& Freddy Sweet (2004) dalam zubaedi bahwa character education is the deliberate effort to help people. Care about. And act upon core ethcal value (Pendidikan karakter adalah usaha sengaja (sadar) untuk membantu memahami, peduli tentang, dan melaksanakan nilai-nilai etika inti. (Zubaedi, 2013: 15).

Akhmad Muhaimin Azzet (2011:27), mengatakan bahwa pendidikan karakter adalah pendidikan budi pekerti plus, yaitu melibatkan aspek pengetahuan (cognitive), perasaan (feeling), dan tindakan (action). Menurut Thomas Licona, 2015: 81-82), 
karakter terdiri dari nilai operatif, nilai dalam tindakan. Proses karakter seiring menjadi suatu nilai dalam tindakan, suatu disposisi batin yang dapat diandalkan untuk menanggapi situasi dengan cara yang menurut moral itu baik. Karakter yang terasa demikian memiliki tiga bagian yang saling berhubungan: pengetahuan moral, perasaan moral, dan perilaku moral.

Pendidikan Karakter menurut Ratna Megawangi (2007: 93) adalah sebuah usaha untuk mendidik anak-anak agar dapat mengambil keputusan dengan bijak dan mengaplikasikan hal tersebut dalam kehidupan sehari-harinya, sehingga mereka dapat memberikan sumbangsih yang positif kepada lingkungan sekitarnya.Nilai-nilai karakter yang perlu ditanamkan kepada anak-anak adalah nilai-nilai universal yang mana seluruh agama, tradisi, dan budaya pasti menjunjung tinggi nila-nilai tersebut.Nilai-nilai universal ini harus dapat menjadi perekat bagi seluruh anggota masyarakat walaupun berbeda latar belakang budaya, suku, dan agama.

Berdasarkan pengertian di atas dapat dipahami, bahwa karakter identik dengan akhlak, sehingga karakter merupakan penanaman nilai-nilai perilaku manusia yang universal yang meliputi seluruh aktivitas manusia, baik dalam rangka berhubungan dengan Tuhannya, dengan dirinya, dengan sesama manusia maupun dengan lingkungan alam sekitar, yang terwujud dalam pikiran, sikap, perasaan, perkataan, dan perbuatan berdasarkan norma-norma agama, hukum, tata krama, budaya, dan adat istiadat. Dari konsep karakter ini muncul konseppendidikan karakter (character education).

Nilai karakter untuk pendidikan karakter meliputi: nilai religius, jujur, toleransi, disiplin, kerja keras, kreatif, mandiri, demokratis, rasa ingin tahu, semangat kebangsaan, cinta tanah air, menghargai prestasi, bersahabat/komunikatif, cinta damai, gemar membaca, peduli lingkungan, peduli sosial dan tanggung jawab.(Said Hamid, 2010).Jika diperhatikan nilai karakter tersebut memiliki kesamaan dengan penjabaran hakikat IPA sebagai sikap.Artinya nilai karakter yang dikembangkan terintegrasi dalam sikap ilmiah siswa.

\section{Pilar Pendidikan Karakter}

Pendidikan karakter di Indonesia di dasarkan pada sembilan pilar karakter dasar.Karakter dasar menjadi tujuan pendidikan karakter. Kesembilan pilar karakter dasar dalam Zubaidi, (2013: 72) antara lain:

1. Religius

2. Tanggung jawab

3. Disiplin

4. Mandiri

5. Jujur

6. Hormat dan santun

7. Kasih sayang, peduli, dan kerja sama

8. Percaya diri, kreatif, kerja keras, dan pantang menyerah

9. Keadilan dan kepemimpinan

10 Baik dan rendah hati 
11 Toleransi, cinta damai, dan persatuan.

Jumlah dan jenis yang dipilih tentu akan dapat berbeda antara satu daerah atau sekolah yang satu dengan yang lain, tergantung pada kepentingan dan kondisinya masing-masing. Sebagai contoh, pilar toleransi, kedamaian, dan kesatuan menjadi sangat penting untuk ditonjolkan karena kemajemukan bangsa dan Negara. (Jamal Ma'mur Asmani, 2012:53).

Selain itu dalam landasan dasar dari pada pendidikan karakter sesuai dengan UU Sisdiknas No. 20 Tahun 2003 (2011: 3).yaitu :"Pendidikan adalah usaha sadar terencana untuk mewujudkan suasana belajar dan proses pembelajaran agar peserta didik secara aktif mengembangkan potensi dirinya untuk memiliki kekuatan spiritual keagamaan, pengenalan diri, kepribadian, kecerdasan, akhlak mulia, serta ketrampilan yang diperlukan dirinya, masyarakat, bangsa dan Negara".

Pendidikan karakter didasarkan pada UU Sisdiknas karena dalam uraian undang-undang tersebut salah satu tujuan dari pendidikan adalah dapat mengembangkan potensi manusia.Yang mana arah dari pengembangan potensi tersebut adalah terwujudnya akhlak mulia.Hal ini sesuai dengan maksud dan tujuan dari pada pendidikan karakter.

William Kilpatrick menyebutkan yang sebagaimana yang dinyatakan dalam Ahmad Tafsir 2013: 31)bahwa salah satu penyebab ketidakmampuan seseorang berlaku baik meskipun ia telah memiliki pengetahuan tentang kebaikan itu (moral knowing) adalah karena ia tidak terlatih untuk melakukan kebaikan (moral doing). Menurut Ahmad Tafsir kesuksesan pendidikan karakter sangat bergantung pada ada tidaknya knowing, loving, dan doing atau acting dalam penyelenggaraan pendidikan karakter.

Moral knowing sebagai aspek pertama memiliki unsur, yaitu :

1. Kesadaran moral (moral awareness)

2. Pengetahua tentang nilai-nilai moral (knowing moral value)

3. Penentuan sudut pandang (perspectivetaking)

4. Logika moral (moral reasoning)

5. Keberanian mengambil menentukan sikap (decisionmaking)

6. Pengenalan diri

Moral Feeling sebagai aspek yang ke dua merupakan aspek yang harus ditanamkan kepada anak yang merupakan sumber energi diri manusia sesuai dengan prinsip moral. Terdapat enam hal yang merupakan aspek emosi yang harus dirasakan oleh seseorang untuk menjadi manusia berkarakter, yakni (1) conscience (nurani), (2) self esteem (percaya diri), (3) empathy (merasakan penderitaan orang lain), (4) loving the good (mencintai kebenaran), (5) self control (mampu mengontrol diri), (6) humility (kerendahan hati). (Masnur Muslich, 2013: 134).

Moral action atau tindakan moral sebagaimana membuat pengetahuan moral dapat diwujudkan menjadi tindakan nyata. Untuk memahami apa yang mendorong sesorang dalam perbuatan yang baik (Act Morally) maka ada tiga aspek dari karakter, yaitu kompetensi (Competence), Keinginan (will), dan kebiasaan (habit). 
Menurut Thomas Lickona, (2015: 100)dalam pribadi dengan karakter yang baik, pengetahuan moral, perasaan moral, dan tindakan moral secara umum berkerjasama untuk saling mendukung satu sama lain. Tentu saja, hal ini tidaklah selalu demikian, bahkan orang yag baik tidak terkecuali sering gagal dalam melakukan perbuatan moral mereka yang terbaik. Namun, seiring kita mengembangkan karakter-proses seumur hidup-kehidupan moral yang kita jalani secara meningkat mengintegrasikan penilai, perasaan, dan pola pelaksanaan perbuatan yang baik.

\section{Pembelajaran IPA}

IPA sendiri berasal dari kata sains yang berarti alam.Sains merupakan "pengetahuan hasil kegiatan manusia yang bersifat aktif dan dinamis tiada hentihentinya serta diperoleh melalui metode tertentu yaitu teratur, sistematis, berobjek, bermetode dan berlaku secara universal" Suyoso (1998).

Pembelajaran IPA merupakan "pengetahuan teoritis yang diperoleh atau disusun dengan cara yang khas atau khusus, yaitu dengan melakukan observasi, eksperimentasi, penyimpulan, penyusunan teori, eksperimentasi, observasi dan demikian seterusnya kait mengkait antara cara yang satu dengan cara yang lain". Maka dapat disimpulkan bahwa IPA merupakan pengetahuan dari hasil kegiatan manusia yang diperoleh dengan menggunakan langkah-langkah ilmiah yang berupa metode ilmiah dan dididapatkan dari hasil eksperimen atau observasi yang bersifat umum sehingga akan terus di sempurnakan.(Abdullah Aly \& Eny Rahma, 1998).

Dalam pembelajaran IPA mencakup semua materi yang terkait dengan objek alam serta persoalannya. Ruang lingkup IPA yaitu makhluk hidup, energi dan perubahannya, bumi dan alam semesta serta proses materi dan sifatnya. IPA terdiri dari tiga aspek yaitu Fisika, Biologi dan Kimia.Pada aSpek Fisika IPA lebih memfokuskan pada benda-benda tak hidup.Pada sapek Biologi IPA mengkaji pada persoalan yang terkait dengan makhluk hidup serta lingfkungannya.Sedangkan pada aspek Kimia IPA mempelajari gejala-gejala kimia baik yang ada pada makhluk hidup maupun benda tak hidup yang ada di alam.

Pendidikan IPA dapat pula diartikan sebagai suatu usaha yang dilakukan secara sadar untuk mengungkap gejala-gejala alam dengan menerapkan langkah-langkah ilmiah serta untuk membentuk kepribadian atau tingkah laku siswa sehingga siswa dapat memahami proses IPA dan dapat dikembangkan di masyarakat.

Pendidikan IPA menjadi suatu bidang ilmu yang memiliki tujuan agar setiap siswa terutama yang ada di sekolah memiliki kepribadian yang baik dan dapat menerapkan sikap ilmiah serta dapat mengembangkan potensi yang ada di alam untuk dijadikan sebagai sumber ilmu dan dapat diterapkan dalam kehidupan sehari-hari.

Dengan demikian pendidikan IPA bukan hanya sekedar teori akan tetapi dalam setiap bentuk pengajarannya lebih ditekankan pada bukti dan kegunaan ilmu tersebut. Bukan berarti teori-teori terdahulu tidak digunakan, ilmu tersebut akan terus digunakan sampai menemukan ilmu dan teori baru. Teori lama digunakan sebagai pembuktian dan penyempurnaan ilmu-ilmu alam yang baru. Hanya saja teori tersebut bukan untuk 
dihapal namun di terapkan sebagai tujuan proses pembelajaran. Melihat hal tersebut di atas nampaknya pendidikan IPA saat ini belum dapat menerapkannya.

Perlu adanya usaha yang dilakukan agar pendidikan IPA yang ada sekarang ini dapat dilaksanakan sesuai dengan tujuan awal yang akan dicapai, karena kita tahu bahwa pendidikan IPA tidak hanya pada teori-teori yang ada namun juga menyangkut pada kepribadian dan sikap ilmiah dari peserta didik. Untuk itu maka kepribadian dan sikap ilmiah perlu ditumbuhkan agar menjadi manusia yang sesuai dari tujuan pendidikan.

\section{Pembelajaran IPA Dalam Membangun Karakter Anak}

Pembelajaran IPA dapat dilakukan dengan bermacam-macam metode, pendekatan, dan modelpembelajaran yang cocok yaitu melalui pengalaman langsung (learning by doing)karena IPA merupakan bagian dari kehidupan manusia.Pembelajaran langsung berpusat pada siswa dandapat memperkuat daya ingat siswa. Pelaksanaan pembelajaran IPA di sekolah yang melibatkan ketiga hakikat IPA, mensyaratkan bahwa pembelajaran tidak sekedar perolehan ilmu pengetahuan yang berupa fakta, konsep, maupun prinsip tetapi juga mengedepankan proses dan sikap ilmiah.

National Science Educational Standard (NSES) (1996) menyatakan," learning science is an active process. Learning science is something student to do, not something that is done to them". Proses pembelajaran IPA memberikan kesempatan kepada siswa untuk melibatkan segala keterampilan proses yang dimiliki. Sebagai contohnya ketika siswa sedang melakukan eksperimen/ percobaan, siswa menempuh langkah-langkah percobaan yakni mengambil data.Ketika anak mengambil data anak harus jujur terhadap data yang diambil, artinya anak tidak diperkenankan untuk memanipulasi data meskipun data yang diperoleh tidak sesuai dengan teori.

Percobaan apabila tidak dilandasi kejujuran akan menyebabkan hal yang fatal. Apabila siswa memaknai sikap ini, maka jujur akan senantiasa melandasi sikapnya dalam kehidupan sehari-hari yang akhirnya dibawa sampai pada masa dewasa yang akan membentuk karakter siswa. Dengan adanya sikap jujur, makabudaya mencontekakan berkurang. Pada jangkauan yang lebih luas, dengan adanya sikap jujur angka korupsi yang semakin merajalela dapat ditanggulangi.Pada beberapa percobaan,tidak dipungkiri adanya kegagalan. Beberapa siswa mungkin akan mengulang percobaan untuk meyakinkan dirinya bahwa apa yang dilakukan sesuai dengan prosedur yang ditentukan.

Hal ini menunjukkan sikaptidak mudah putus asa, sikap hati-hati serta memiliki rasa ingin tahu yang tinggi. Apabila sikap ini diinternalisasi siswadengan baik maka akan membentuk terbentuk karakter yang baik. Melalui sikap tidak mudah putus asa, siswa akan berusaha lebih keras untuk memperoleh apa yang dicita-citakan. Siswa tidak akan menghalalkan berbagai cara untuk mendapatkan hasil yang diinginkan. Melalui sikap hati-hati yang dimiliki siswa tidak akan gegabah dalam menanggapi suatu permasalahan. Melalui sikap-sikap tersebut siswa akan mampu menghadapi tantangan masa depan yang semakin kompleks dengan bijaksana. 
Tidak jarang dalam melakukan percobaan siswa melakukan dalam kelompok. Sehingga akan mendorong siswa untuk berinteraksi dan bekerjasama dengan teman sebaya. Melalui aktivitas ini akan mengembangkan karakter siswa dalam berkomunikasi. Kerjasama juga akan memupuk rasa peduli terhadap sesama. Dari beberapa pernyatan tersebut tampak bahwa pembelajaran IPA mampu memberikan kontribusi dalam membangun karakter anak.

\section{Metode Penelitian}

Lokasi dan Subyek Penelitian dilakukan di MIN Pemangkat Kabupaten Sambas yang beralamat di Jalan Penjajap Timur Kecamatan Pemangkat Kabupaten Sambas.Subyek penelitian dalam penelitian ini ada 101 siswa kelas V MIN Pemangkat Kabupaten Sambas.Jenis penelitian yang penulis gunakan adalah penelitian lapangan (field research) dengan pengumpulan data yang dilakukan secara langsung di lokasi penelitian untuk memperoleh informasi terkait implementasi pendidikan karakter, nilainilai karakter yang ditanamkan dalam pembelajaran IPA di MIN Pemangkat Kabupaten Sambas.Sedangkan pendekatan penelitian yang dilakukan adalah menggunakan pendekatan deskriptif kualitatif.

Metode pengumpulan data dalam penelitian ini adalah, metode observasi, wawancara, angket, dan dokumentasi.Sementara alat yang digunakan untuk mengumpulkan data dalam penelitian adalah pedoman observasi, pedoman wawancara dan pedoman angket dengan menyiapkan alat pengumpul data berupa buku catatan, kamera, perekam (tape recorder), dan lain-lain yang dianggap bisa membantu penelitian. Adapun tahapan penelitian ini yaitu pra penelitian yang terdiri dari (memilih topik kajian dan instrumentasi penelitian), Penelitian (ini dilakukan setelah proposal penelitian disetujui dan telah mendapat izin penelitian), dan Penelitian penutup berupa pengolahan data melalui reduksi data, display data dan analisa data penelitian. Analisis data dalam penelitian ini adalah; data collection, data reduction, data display, dan conclution. Keabsahan data dalam penelitian ilmiah mutlak diperlukan untuk mengetahui keabsahan data pada penelitian. Untuk itu langkah-langkah untuk menjaga keabsahan data dalam penelitian ini adalah; memperpanjang masa observasi, pengamatan yang terus menerus, triangulasi, membincangkan dengan orang lain dalam bentuk diskusi-diskusi terbatas (focus group discussion) dan membercheck.

\section{Hasil Penelitian dan Pembahasan}

Karakter yang akan didapatkan dalam proses pembelajaran di kelas dengan harapan bahwa selain siswa unggul dibidang akademik serta memiliki kompetensi yang baik (competence), mereka juga memiliki kepribadian yang utuh dimana dapat memiliki nilai-nilai pendidikan karakter terdiri dari lima nilai utama :(1) Kasih, (2) Disiplin, (3) Cerdas, (4) Berani, dan (5) Kejujuran yang pada akhirnya dapat menjadi pribadi yang dapat bermanfaat untuk sesamanya yang kesemuanya. 
Berdasarkan dari hasil penelitian dan pembahasan yang penulis uraikan tentang implementasi pendidikan karakter dalam pembelajaran IPA di MIN Pemagkat Kabupaten Sambas, maka akhirnya dapat diambil kesimpulansebagai berikut.

1. Implementasi pendidikan karakter dalam pembelajaran IPA di MIN Pemagkat Kabupaten Sambas dilaksanakan dalam tiga tahapan yaitu perencanaan, pelaksanaan, evaluasi dan tindak lanjut. Pada tahapan perencanaan, kegiatan rancangan yang disusun meliputi penyusunan kurikulum Madrasah, pengembangan silabus, penyusunan RPP, persiapan bahan/buku ajar, penyiapan media dan alat peraga IPA, menggunakan berbagai metode dan strategi pembelajaran. Kemudian pada tahapan pelaksanaan, pendidik mapel IPA menjalankan rancangan yang telah disusun untuk diterapkan dalam kegiatan pembelajaran yang meliputi kegiatan pendahuluan (awal), kegiatan inti dan kegiatan penutup (akhir). Pada tahapan evaluasi dan tindak lanjut, evaluasi yang dilakukan menggunakan teknik penilaian tes (uraian terbatas dan isian) dan nontes (observasi, portofolio, unjuk kerja, laporan dan proyek). Tindak lanjut yang dilakukan antara lain memberikan tugas individu/kelompok (PR), kegiatan proyek, kegiatan jam tambahan belajar (les), menasihati secara klasikal dan memberikan bimbingan serta arahan kepada peserta didik yang memerlukan penanganan khusus.

2. Nilai-nilai karakter yang ditanamkan dalam pembelajaran IPA di MINPemangkat Kabupaten Sambas terdiri atas nilai-nilai karakter prioritas dan nilai-nilai karakter pendukung. Nilai-nilai karakter prioritas merupakan nilai-nilai karakter yang wajib ditanamkan pendidik dalam kegiatan pembelajaran IPA. Nilai-nilai karakter prioritas yang ditanamkan meliputi nilai jujur, disiplin, kerja keras dan tanggung jawab. Nilai-nilai karakter pendukung ialah nilai-nilai karakter yang dikembangkan pendidik untuk mendukung penanaman nilai-nilai karakter prioritas supaya dapat berjalan dengan baik. Nilai-nilai karakter pendukung yang ditanamkan yaitu kebersamaan, mandiri, rasa ingin tahu, gemar melakukan, teliti, kerjasama, percaya diri, keberanian, religius dan peduli lingkungan.

\section{Kesimpulan}

Pendidikan karakter perlu ditanamkan dalam proses pembelajaran ke dalam diri anak sebagai peserta didik yang bertujuan untuk mengembangkan potensi peserta didik agar menjadi manusia berhati baik, berpikiran baik, dan berperilaku baik. Salah satunya yakni melalui pembelajaran IPA. Hal ini dikarenakan dalam pembelajaran IPA selain terdapat aspek produk dan proses juga terdapat aspek sikap. Nilai karakter memiliki kesamaan dengan penjabaran hakikat IPA sebagai sikap.Artinya nilai karakter yang dikembangkan terintegrasi dalam sikap ilmiah siswa.Adanya pembentukan sikap yang baik dari peserta didik diharapkan dapat membentuk karakter yang baik pula, sehingga diharapkan dapat membangun kehidupan bangsa yang lebih berhasil.Karena keberhasilan suatu bangsa dapat dicerminkan melalui kualitas sumber daya manusia di dalamya. 
Implementasi Pendidikan Karakter Dalam Pembelajaran IPA di MIN Pemangkat Kabupaten Sambas Kalimantan Barat

Purniadi Putra

Implementasi pendidikan karakter dalam pembelajaran IPA di MIN Pemagkat Kabupaten Sambas dilaksanakan dalam tigatahapan yaitu perencanaan, pelaksanaan, evaluasi dan tindak lanjut.Nilai-nilai karakter yang ditanamkan dalam pembelajaran IPA di MINPemangkat Kabupaten Sambas terdiri atas nilai-nilai karakter prioritas dan nilainilai karakter pendukung.Nilai-nilai karakter prioritas merupakan nilai-nilai karakter yang wajib ditanamkan pendidik dalam kegiatan pembelajaran IPA.Nilai-nilai karakter prioritas yang ditanamkan meliputi nilai jujur, disiplin, kerja keras dan tanggung jawab.

\section{Daftar Pustaka}

Abdullah Aly \& Eny Rahma. 1998. Ilmu Alamiah Dasar. Jakarta: Bumi Aksara.

Akhmad Muhaimin Azzet. 2011. Urgensi Pendidikan Karakter di Indonesia. Jogjakarta: AR-Ruzzmedia.

Asmani, Jamal Ma'mur. 2012. Buku Panduan Internalisasi Pendidikan Karakter di Sekolah. Jogjakarta: DIVA Press.

Doni Koesoema, A. 2007. Pendidikan Karakter: Strategi Mendidik Anak di Zaman Global. Jakarta: Grasindo.

Islam, Amjad Pitafi and Muhammad Farooq. 2012. "Measurement of Scientific Attitude of Secondary School Students in Pakistan": Academic Research International Vol. 2, No. 2, March 2012. ISSN-L: 2223-9553.

Lickona, Thomas. 1991. Educating for Character: How Our School Can Teach Respect and Responsibility. New York, Toronto, London, Sydney, Aucland: Bantam Books.

Licona, Thomas. 2015. Educating For Character; Mendidik Untuk Membentuk Karakter, terj. Juma Abdu Wamaungo.Jakarta: Bumi Aksara.

Masnur Muslich. 2013. Pendidikan Karakter Menjawa Tantangan Krisis Multidimensional.Jakarta: Bumi Aksara.

Muchlas Samani \& Hariyanto. 2011. Konsep dan Model Pendidikan Karakter.Bandung: PT Remaja Rosdakarya.

Muslich, Masnur. 2013. Pendidikan Karakter Menjawa Tantangan Krisis Multidimensional.Jakarta: Bumi Aksara.

Ratna Megawangi. 2007. Pendidikan Karakter Solusi Yang Tepat Untuk Membangun Bangsa.Jakarta: Indonesia Heritage Foundation.

Said Hamid. 2010. Pengembangan Pendidikan Budaya dan Karakter Bangsa.Jakarta: Kemendiknas Badan Penelitian dan Pengembangan Kurikulum.

Tafsir, Ahmad. 2013.Pendidikan Karakter Perspektif Islam.Bandung: PT. Remaja Rosdakarya.

Teungku Muhammad Hasbi Ash Shiddiqi. 2002. Tafsir Al Bayan. Semarang: Pustaka Rizki Putra.

Tim Redaksi Tessaurus Bahasa Indonesia. 2008.Tesaurus Bahasa Indonesia Pusat Bahasa.Jakarta: Departemen Pendidikan Nasional.

Trianto. 2010. Model Pembelajaran Terpadu: Konsep, Strategi, dan Implementasinya dalam Kurikulum Tingkat Satuan Pendidikan (KTSP), Cet Kemendiknas RI, Lampiran Permendiknas Nomor 22 Tahun 2006 Tentang Standar Isi: untuk Satuan Pendidikan Dasar dan Menengah.Jakarta: Bumi Aksara.

Undang-Undang. 2011. Sistem Pendidikan Nasional.Yogyakarta: Pustaka Pelajar. 
JIP: Jurnal Ilmiah PGMI

Volume 3, Nomor 1, Juni 2017

Zubaedi. 2013.Desain Pendidikan Karakter:Konsepsi dan Aplikasinya dalam Lembaga Pendidikan.Jakarta: Kencana.

Zuhdan K. Prasetyo. 2013. Bahan Ajar Pemantapan Penguasaan Materi Pendidikan Profesi Guru Ilmu Pengetahuan Alam (IPA), Konsep Dasar Pendidikan IPA. Yogyakarta: UNY. 